\title{
Fertility capability soil classification: a tool to help assess soil quality in the tropics
}

\author{
Pedro A. Sanchez ${ }^{\mathrm{a}, *}$, Cheryl A. Palm ${ }^{\mathrm{a}}$, Stanley W. Buol ${ }^{\mathrm{b}}$ \\ ${ }^{a}$ Ecosystem Sciences Division, Department of Environmental Science, Policy and Management, \\ University of California, Berkeley, CA 94720-3110, USA \\ ${ }^{\mathrm{b}}$ Soil Science Department, North Carolina State University, Raleigh, NC 27695-7619, USA
}

\begin{abstract}
The soil quality paradigm was originally developed in the temperate region with the overarching objective of approaching air quality and water quality standards. Although holistic and systemsoriented, soil quality focused principally on issues arising from large nutrient and energy inputs to agricultural lands. Soil quality in the tropics, however, focuses on three overarching concerns: food insecurity, rural poverty and ecosystem degradation. Soil science in the tropics relies heavily on quantitative attributes of soils that can be measured. The emotional, value-laden and "measure everything" approach proposed by some proponents of the soil quality paradigm has no place in the tropics. Soil quality in the tropics must be considered a component of an integrated natural resource management framework (INRM). Based on quantitative topsoil attributes and soil taxonomy, the fertility capability soil classification (FCC) system is probably a good starting point to approach soil quality for the tropics and is widely used. FCC does not deal with soil attributes that can change in less than 1 year, but those that are either dynamic at time scales of years or decades with management, as well as inherent ones that do not change in less than a century. FCC attributes can be positive or negative depending on the land use as well as the temporal and spatial scales in question. Version 4 is introduced in this paper. The main changes are to include the former $h$ condition modifier (acid, but not Al-toxic) with "no major chemical limitations" because field experience has shown little difference between the two and to introduce a new condition modifier $m$ that denotes organic carbon saturation deficit. Additional modifiers are needed for nutrient depletion, compaction, surface sealing and other soil biological attributes, but there is no sufficient evidence to propose robust, quantitative threshold values at this time. The authors call on those actively involved in linking these attributes with plant growth and ecosystem functions to provide additional suggestions that would enhance FCC. The use of diffuse reflectance spectroscopy (DRS) shows great potential on a wide range of tropical soils. The evolution of soil science from a qualitative art into a
\end{abstract}

* Corresponding author. The Earth Institute at Colombia University, Lamont Hall, PO Box 1000, Palisades, NY 10964, USA. Tel.: +1-646-244-1720; fax: +1-510-217-9717.

E-mail addresses: p.sanchez@cgiar.org (P.A. Sanchez), c.palm@cgiar.org (C.A. Palm), stanley_buol@ncsu.edu (S.W. Buol). 
quantitative science has progressed well in the tropics. Regressing to qualitative and vaguely defined soil quality attributes would be a step backwards.

(C) 2003 Elsevier Science B.V. All rights reserved.

Keywords: Soil attributes; Tropical soils; Soil taxonomy; Integrated natural resource management; Organic carbon saturation; Diffuse reflectance spectroscopy

\section{Introduction}

The development of the soil quality paradigm stems largely from initiatives in industrialized countries of the temperate zone during the 1990s (Doran et al., 1994; Doran and Jones, 1996; Karlen et al., 1997). Soil quality has been defined as "the capacity of a soil to function within land use and ecosystem boundaries, to sustain biological productivity, maintain environmental quality and promote plant, animal and human health" (Doran and Parkin, 1994, 1996). This concept departs from the traditional agricultural approach focusing on the productive functions of soils, shifting to a more holistic one that recognizes the various roles soils play in agroecosystems and natural systems (Karlen et al., 1997; Swift, 1999). Soil quality attributes are biological, chemical and physical parameters that can be quantified at specific temporal scales.

Soil science in the tropics developed later than in the temperate regions and operates on somewhat different paradigms (Sanchez, 1994, 1997; Swift, 1999). Many of the myths associated with the geographical distribution and productivity of tropical soils are now dispelled (Lal and Sanchez, 1992). Soils in the tropics are regarded by the international policy community as increasingly important in world development issues such as food security, poverty alleviation, land degradation and the provision of environmental services (Wood et al., 2000; Sanchez, 2002b).

Unlike the temperate zone, the overarching concerns about soils in the tropics relate to food insecurity, rural poverty and their effects on ecosystem degradation (PinstrupAndersen et al., 1999). The main soil-environmental concerns in tropical countries are not related so much to nutrient pollution as in the temperate zone but rather to the opposite-nutrient depletion as well as the loss of soil organic matter (SOM) and its related functions (Smaling, 1993; Sanchez et al., 1997). The major environmental concerns the tropics shares with the temperate region are soil erosion, declining biodiversity, watershed hydrology and adaptation to and mitigation of climate change.

There are exceptions to all the above statements because the tropics encompass a wide variety of agricultural and social systems. Parts of Brazil, Mexico and South Africa practice the kind of mechanized, large-scale agriculture, typical of North America and Europe, and face similar soil quality challenges, including nutrient pollution. This paper focuses on situations faced primarily by smallholder farmers across the tropics, with emphasis on Africa, because this is where the most acute problems are.

The objective of this paper is to indicate how an updated fertility capability soil classification (FCC) system can be used to identify attributes relevant for plant production and overall ecosystem management in the tropics. We first discuss an overall integrated 
natural resource management framework (INRM) that puts soil attributes into a broad context; this is followed by quantitative pedology as the entry point for FCC, the fourth version of this system, the search for biological soil attributes and a general discussion.

\section{The integrated natural resource management framework (INRM)}

In our opinion, soil quality must be viewed within a broader context, as a component of an integrated natural resource management framework (INRM), which fits with current soil quality concepts. The soil component is an integral part of this INRM approach (Dumanski et al., 1998). An INRM research framework, shown in Fig. 1, has been developed by the international agricultural research centers, after years of experimentation with ways to do cross-disciplinary research. INRM is defined as "the sustainable use of the resource base of agriculture, in order to meet the production goals of farmers as well as

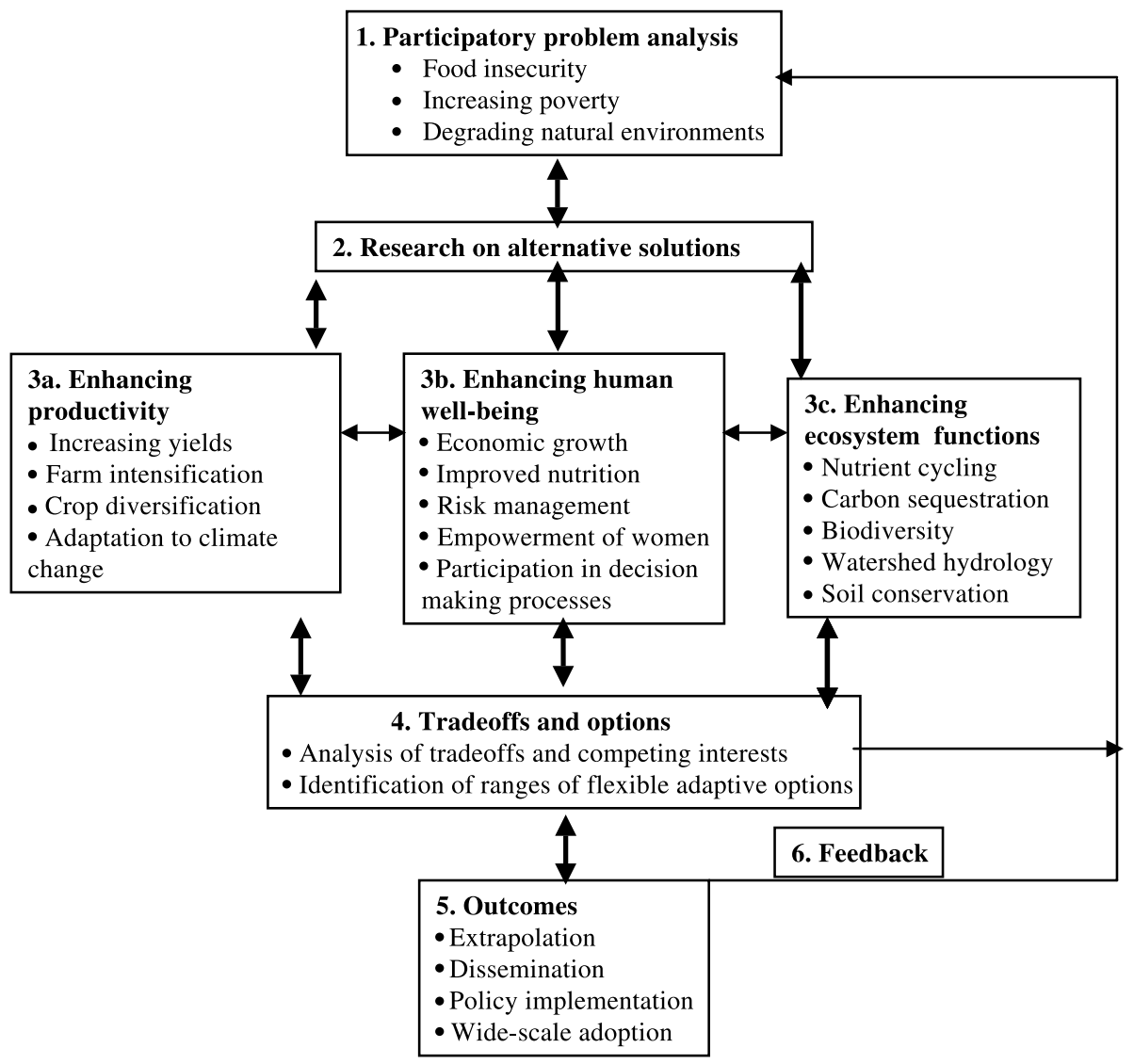

Fig. 1. Model of the integrated natural resource management research process for use by the international agricultural research community. Source: CIFOR (2000), modified by the authors of this paper. 
the goals of the rest of the community, and the preservation and enhancement of the global environment" (CIFOR, 2000; Izac and Sanchez, 2001).

In this framework, problems are identified in a participatory, quantitative and multidisciplinary manner, involving farmers and policymakers from day 1 (Step 1). Scientists involved represent various natural and social sciences. Gone are the days when a soil scientist could conceive an idea, test it in replicated small plots within the confines of an experiment station and give the results to extension workers to recommend to farmers in the tropics. Today's problems are more complex than that.

Interdisciplinary research on alternative solutions then follows (Step 2), using the entry points identified in the first step. Soil scientists, plant breeders, plant pathologists, foresters, livestock specialists and others focus on the production dimension as appropriate (Step 3a). Several social science disciplines are involved in the human well-being dimension, particularly economics, anthropology, sociology and geography (Step 3b). Ecologists, including soil and plant ecologists, focus on the ecosystem resilience dimension along with resource economists (Step 3c).

Since agroecosystems are driven by the interaction between ecological, economic and social variables, INRM research has to work back and forth across these three dimensions, as well as at various scales in time and space. When results are apparent, a tradeoff analysis is performed between farmer private benefits (both production and human well-being) and global environmental benefits such as biodiversity protection and carbon sequestration (Step 4). This analysis provides a range of flexible, adaptive options (not a silver bullet) for farmers and policymakers to decide. Scaling-up starts, in many cases, with on-farm research (Franzel and Scherr, 2002), followed by Step 5, pilot development projects and large-scale adoption (Franzel et al., 2001). Feedback is needed at all stages, and the loop is closed with Step 6.

This framework, with appropriate local modification, fits well with the holistic concept of soil quality (Doran and Parkin, 1996; Doran and Jones, 1996; Karlen et al., 1997) as well with the need for scientific rigor at all stages of the research-development continuum as articulated by Sojka and Upchurch (1999).

\section{Quantitative pedology: the entry point}

Quantitative pedology is based on soil taxonomy (Soil Survey Staff, 1999), the World Reference Base for Soil Resources (Deckers et al., 1998) and the digitized world soils map (FAO, 1995a). The parameters measured in soil taxonomy have been carefully selected as those necessary for classifying soils as natural bodies. Through soil surveys and geographic information systems, pedon data is scaled-up to larger spatial scales, including higher resolution national, provincial and municipality maps, agroecological zone mapping (FAO, 1981) and digitized soil and terrain databases (FAO, 1995b).

Differences in quantitative pedology are important to establish the broad picture of soils as natural bodies, but what does it mean in agronomic or ecological terms? The limitation of soil taxonomy, the FAO legend and the World Reference Base for Soil Resources is that they quantify only permanent soil attributes, most of which are located in the subsoil. In a quest to identify undisturbed soil and cultivated soil in the same taxa, these soil classification 
systems ignore many inherent or dynamic attributes crucial to plant productivity. These are located mostly in the topsoil, where the majority of plant roots are, both in natural ecosystems and agroecosystems.

\section{Fertility capability classification and its relevance to soil quality}

To overcome this limitation, the fertility capability soil classification (FCC) system was developed over 25 years ago to interpret soil taxonomy and additional soil attributes in a way that is directly relevant to plant growth (Buol et al., 1975; Buol and Couto, 1981; Sanchez et al., 1982).

The initial version of FCC (Buol et al., 1975; Buol and Couto, 1981;Sanchez et al., 1982) was succeeded by a second version (Sanchez and Buol, 1985; Buol, 1986), which includes specific interpretations for wetland rice soils. A third version (Smith, 1989; Smith et al., 1990) added a new condition modifier for permafrost and subdivisions of some existing ones. Smith (1989) also developed a thorough rationale for each FCC class and provided detailed interpretations for tropical food crops, pastures and tree crops. An algorithm of this third version was later developed by Yost et al. (1997) with software that converts soil profile data into FCC units plus a series of automatic interpretations and recommendations (http://www.fao.org/ag/AGL/AGLL/fcc3/faorep.htm).

The FCC system is widely used. It is included in the worldwide FAO digitized soils map at a resolution of $10 \mathrm{~km}^{2}$ (FAO, 1995a). It is used at national and provincial scales in several countries such as Brazil (Oliveira, 1978), Venezuela (Avilán et al., 1979; Brito et al., 1979), Taiwan (Lin, 1984, 1985), United States (Denton et al., 1986), Thailand (Euimnoh, 1984), Indonesia (Sornsumran, 1985), Peru (Paredes, 1986) and Cambodia (White et al., 1997). At the regional scale, FCC has been used in South America (Cochrane et al., 1985) and in the Caribbean for pine plantations (Liegel, 1986). FCC is used at the global scale by the World Resources Institute (1990, 1992), by FAO (1995a) and in the pilot analysis of global agroecosystems (Wood et al., 2000).

But is FCC relevant to soil quality? One important aspect of soil quality is that it deals with soil attributes across temporal and spatial scales. Although dynamic, quantitative attributes most sensitive to changes in land use are the most desirable as soil quality indicators (Doran and Parkin, 1996), the importance of inherent, albeit static, soil attributes is recognized as an important component of soil quality (Karlen et al., 1997). FCC was originally conceived as dealing only with inherent soil properties that are the product of soil genesis and cannot be easily changed with time (Sanchez et al., 1982). FCC considers topsoil parameters as well as specific subsoil properties. This is why the FCC system does not include routine soil tests used for $\mathrm{N}$ and $\mathrm{P}$ fertilizer recommendations. A further reason is that such soil tests are not very useful in farming systems where fertilizer use is not the main nutrient input (Smithson and Sanchez, 2001). The question is at what time scale are we referring to-days, months, years, decades, centuries?

The FCC system may represent a useful approach to tackling soil quality in the tropics on a quantitative basis. FCC is not equal to soil quality, which is in many instances a difficult concept to put in practice with sufficient scientific rigor. The next section presents the updated version of FCC. 


\section{FCC Version 4}

The FCC system consists of two categorical levels. The first category-type/substrata type - describes topsoil and subsoil texture and is expressed in capital letters ( $\mathrm{S}$ - sandy throughout; $\mathrm{SC}$ - sandy topsoil underlain by a clayey subsoil, for example). The second category - condition modifier - consists of 17 modifiers defined to delimit specific soil conditions affecting plant growth with quantitative limits. Each condition modifier is expressed as a lower case letter. Superscripts + or - indicate a greater or lesser expression of the modifier.

The type/substrata types and condition modifiers are the soil attributes in terms of their capability for plant growth. Several methods are given in order of decreasing preference and reliability but increasing ease of determination for assessing each attribute, following the quantitative approach of soil taxonomy (Soil Survey Staff, 1999). Condition modifiers were originally conceived as soil constraints in the mid-1970s. However, the INRM paradigm and the need to scale-up from a pedon (measured once) to higher temporal and spatial scales have changed interpretations of some modifiers as positive attributes.

Each soil has only one type/substrata type but can have several condition modifiers. For example, a soil classified as Caik is clayey, Al-toxic, high P fixer and low in weatherable mineral content. The FCC designation for a given soil can be interpreted in relation to various land uses. Examples have been developed (Sanchez et al., 1982; Sanchez and Buol, 1985; Smith, 1989; Yost et al., 1997). As indicated before, the latter reference has an expert system algorithm that automatically delivers interpretations for various land uses.

Version 4 is introduced in this paper as Table 1. The main changes are to combine the former $h$ condition modifier (acid, but not Al-toxic) with "no major chemical constraints" because field experience has shown little difference between the two and to introduce a new condition modifier $m$ that denotes a critical decline in soil organic matter. In addition, we changed the symbol of gravel from an apostrophe (') to $r$, for clarity and uniformity, and moved some soil $\mathrm{pH}$ limits slightly.

The reasoning for these changes is as follows. Bringing soils that are acid, but not Altoxic, into the category of "no chemical limitations" was done because soils with the $h$ condition modifier do not behave sufficiently different from those with "no chemical limitations" except when grown to extremely Al-susceptible plants. An $a^{-}$modifier under Al-toxicity now flags this specific situation. For other land uses, $h$ soils defined as having a topsoil $\mathrm{pH}$ range between 5.0 and 6.0 show no major negative attributes. Interpretations of FCC maps depict this mild acidity as a major constraint to plant growth (Wood et al., 2000). With the exception of extremely acid-sensitive crops like cotton and alfalfa, this is not the case. The other major change in Version 4 is the introduction of the first biologically based modifier, and the reasoning behind this is fully developed in a latter section of this paper.

The areal extent of the main FCC classes in the tropics is shown in Table 2. Each FCC condition modifier is discussed below, in descending order of area extensiveness.

\subsection{Soil moisture stress $(d)$}

The presence of dry seasons longer than 3 months is a constraint to year-round crop production in about $60 \%$ of soils in the tropics. But it is also a positive attribute because 
Table 1

Fertility capability soil classification system: Version $4^{\mathrm{a}}$

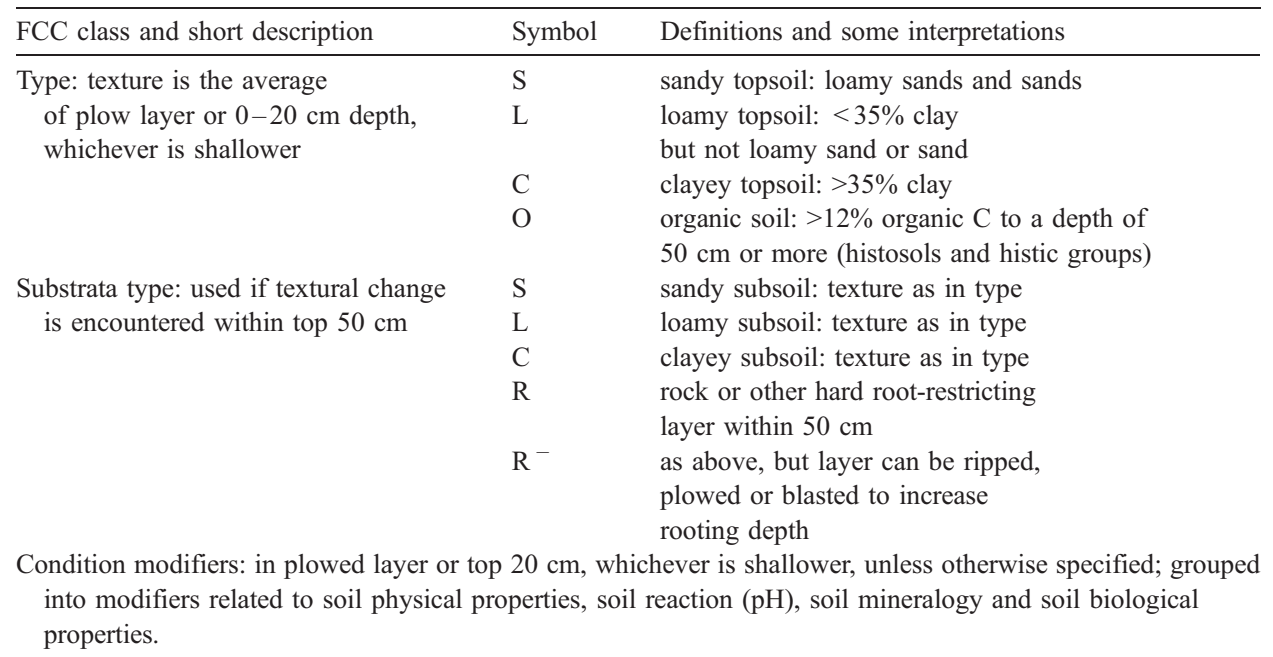

Condition Modifier Identifying criteria (if more than one, they are listed in decreasing desirability)

Modifiers related to soil physical properties

Waterlogging (gley): anaerobic condition, $g$ chemical reduction, denitrification; $\mathrm{N}_{2} \mathrm{O}$ and $\mathrm{CH}_{4}$ emissions

Strong dry season (dry):

limits year-round cropping,

interrupts pest cycles, Birch effect

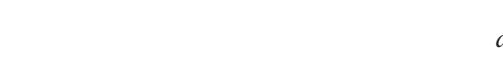

Low soil temperatures aquic soil moisture regime; mottles $<2$ chroma within $50 \mathrm{~cm}$ for surface and below all A horizons or soil saturated with water for $>60$ days in most years prolonged waterlogging; soil saturated with water either naturally or by irrigation for $>200$ days/year with no evidence of mottles indicative of $\mathrm{Fe}^{3+}$ compounds in the top $50 \mathrm{~cm}$; includes paddy rice soils in which an anaerobic crop cannot be grown without drainage; continuous chemical reduction can result in slower soil $\mathrm{N}$ mineralization and $\mathrm{Zn}$ deficiencies in rice ustic or xeric soil moisture regime: dry $>60$ consecutive days/year but moist $>180$ cumulative days/year within $20-60 \mathrm{~cm}$ depth aridic or torric soil moisture regime: too dry to grow a crop without irrigation cryic and frigid $\left(<8{ }^{\circ} \mathrm{C}\right.$ mean annual), non-iso soil temperature regimes, where management practices can help warm topsoils for short-term cereal production permafrost within $50 \mathrm{~cm}$ gelisols; no cropping possible 
Table 1 (continued)

\begin{tabular}{|c|c|c|}
\hline Condition & Modifier & $\begin{array}{l}\text { Identifying criteria (if more than one, } \\
\text { they are listed in decreasing desirability) }\end{array}$ \\
\hline \multicolumn{3}{|l|}{ Modifiers related to soil physical properties } \\
\hline \multirow[t]{3}{*}{ Gravel } & $r^{+}$ & $\mathrm{r}^{+}=10-35 \%$ \\
\hline & $r^{++}$ & $\begin{array}{l}\mathrm{r}^{++} \geq 35 \% \text { (by volume) of gravel size coarse } \\
\text { fragments }(2-25 \mathrm{~cm} \text { in diameter) anywhere } \\
\text { in the top } 50 \mathrm{~cm} \text { of the soil }\end{array}$ \\
\hline & $r^{+++}$ & more than $15 \%$ rock outcroppings \\
\hline Slope & $\%$ & $\begin{array}{l}\text { where desirable place range in } \% \text { slope } \\
\text { (i.e., } 0-15 \% ; 15-30 \% ;>30 \% \text { ) }\end{array}$ \\
\hline High erosion risk & $\begin{array}{l}\mathrm{SC}, \mathrm{LC} \\
\mathrm{CR}, \mathrm{LR} \\
\mathrm{SR},>30 \%\end{array}$ & $\begin{array}{l}\text { soils with high erodibility due to } \\
\text { sharp textural contrasts (SC, LC), } \\
\text { shallow depth (R) or steep ( }>30 \%) \text { slope }\end{array}$ \\
\hline \multicolumn{3}{|l|}{ Modifiers related to soil reaction } \\
\hline Sulfidic (cat clays) & $c$ & $\begin{array}{l}\mathrm{pH}<3.5 \text { after drying; jarosite mottles with hues } \\
2.5 \mathrm{Y} \text { or yellower and chromas } 6 \text { or more within } \\
60 \mathrm{~cm} \text { sulfaquents, sulfaquepts, sulfudepts }\end{array}$ \\
\hline \multirow[t]{2}{*}{$\begin{array}{l}\text { Aluminum toxicity for } \\
\text { most common crops }\end{array}$} & $a$ & $\begin{array}{l}>60 \% \text { Al saturation within } 50 \mathrm{~cm} \text {, or } \\
<33 \% \text { base saturation of } \mathrm{CEC}\left(\mathrm{BS}_{7}\right) \text { determined } \\
\text { by sum of cations at } \mathrm{pH} 7 \text { within } 50 \mathrm{~cm} \text {, or } \\
<14 \% \text { base saturation of } \mathrm{CEC}\left(\mathrm{BS}_{8.2}\right) \text { by sum } \\
\text { of cations at } \mathrm{pH} 8.2 \text { within } 50 \mathrm{~cm} \text {, or } \\
\mathrm{pH}<5.5 \text { except in organic soils }(\mathrm{O})\end{array}$ \\
\hline & $a^{-}$ & $\begin{array}{l}10-60 \% \text { Al saturation within } 50 \mathrm{~cm} \text { for extremely } \\
\text { acid-sensitive crops such as cotton and alfalfa }\end{array}$ \\
\hline $\begin{array}{l}\text { No major chemical limitations } \\
\quad \text { (includes former } h \text { modifier) }\end{array}$ & no symbol & $\begin{array}{l}<60 \% \mathrm{Al} \text { saturation of ECEC within } 50 \mathrm{~cm} \\
\text { and } \mathrm{pH} \text { between } 5.5 \text { and } 7.2\end{array}$ \\
\hline $\begin{array}{l}\text { Calcareous (basic reaction): } \\
\text { common Fe and } \mathrm{Zn} \text { deficiencies }\end{array}$ & $b$ & $\begin{array}{l}\text { free } \mathrm{CaCO}_{3} \text { within } 50 \mathrm{~cm} \\
\text { (fizzing with } \mathrm{HCl} \text { ), or } \mathrm{pH}>7.3\end{array}$ \\
\hline \multirow[t]{2}{*}{ Salinity } & $s$ & $\begin{array}{l}>0.4 \mathrm{~S} \mathrm{~m}^{-1} \text { of saturated extract at } 25{ }^{\circ} \mathrm{C} \\
\text { within } 1 \mathrm{~m} \text {; salids and salic groups; solonchaks }\end{array}$ \\
\hline & $s^{-}$ & $\begin{array}{l}0.2-0.4 \mathrm{~S} \mathrm{~m}^{-1} \text { of saturated extract at } \\
25{ }^{\circ} \mathrm{C} \text { within } 1 \mathrm{~m} \text { (incipient salinity) }\end{array}$ \\
\hline \multirow[t]{2}{*}{ Alkalinity } & $n$ & $\begin{array}{l}>15 \% \text { Na saturation of ECEC within } 50 \mathrm{~cm} \text {; } \\
\text { most solonetz }\end{array}$ \\
\hline & $n^{-}$ & $\begin{array}{l}6-15 \% \mathrm{Na} \text { saturation of ECEC within } 50 \mathrm{~cm} \\
\text { (incipient alkalinity) }\end{array}$ \\
\hline \multicolumn{3}{|l|}{ Modifiers related to soil mineralogy } \\
\hline $\begin{array}{l}\text { Low nutrient capital reserves } \\
\qquad \text { (K deficiencies) }\end{array}$ & $k$ & $\begin{array}{l}<10 \% \text { weatherable minerals in silt and sand } \\
\text { fraction within } 50 \mathrm{~cm} \text {, or siliceous mineralogy, } \\
\text { or exchangeable } \mathrm{K}<0.20 \mathrm{cmol}_{\mathrm{c}} \mathrm{kg}^{-1} \text { soil, or } \\
\text { exchangeable } \mathrm{K}<2 \% \text { of sum of bases, if sum } \\
\text { of bases is }<10 \mathrm{cmol}_{\mathrm{c}} \mathrm{kg}^{-1} \text { soil }\end{array}$ \\
\hline $\begin{array}{l}\text { High } \mathrm{P} \text { fixation by Fe and } \mathrm{Al} \text { oxides } \\
\text { ( }>100 \mathrm{mg} \mathrm{kg}^{-1} \mathrm{P} \text { added to achieve } \\
\text { adequate soil test levels); } \\
\text { Ci soils have excellent structure } \\
\text { but low water holding capacity; } \\
\text { Ci subsoils retain nitrates }\end{array}$ & $i$ & $\begin{array}{l}\text { dithionite-extractable free } \mathrm{R}_{2} \mathrm{O}_{3} \text { : clay ratio }>0.2 \text {, } \\
\text { or }>4 \% \text { citrate dithionite-extractable Fe in of } \\
\text { topsoil, or oxisols and oxic groups with } \mathrm{C} \text { type, } \\
\text { or hues redder than } 5 \mathrm{YR} \text { and granular structure }\end{array}$ \\
\hline
\end{tabular}


Table 1 (continued)

\begin{tabular}{|c|c|c|}
\hline Condition & Modifier & $\begin{array}{l}\text { Identifying criteria (if more than one, } \\
\text { they are listed in decreasing desirability) }\end{array}$ \\
\hline \multicolumn{3}{|l|}{ Modifiers related to soil mineralogy } \\
\hline & $i^{-}$ & $\begin{array}{l}\text { as above, but soils have been recapitalized } \\
\text { with } \mathrm{P} \text { fertilizers to supply long-term } \mathrm{P} \text { to crops; } \\
\text { soil test }>10 \mathrm{mg} \mathrm{kg}^{-1} \mathrm{P} \text { by Olsen method } \\
\text { as above; potential Fe toxicity if } \\
\text { soils waterlogged for long time } \\
\left(\mathrm{g}^{+}\right) \text {or adjacent uplands have } i \text { modifier }\end{array}$ \\
\hline \multirow[t]{2}{*}{$\begin{array}{l}\text { Amorphous volcanic (X-ray amorphous); } \\
\text { high P fixation by allophane } \\
\text { (>200 } \mathrm{mg} \mathrm{kg}^{-1} \mathrm{P} \text { added to achieve } \\
\text { adequate soil test levels); } \\
\text { low N mineralization rates }\end{array}$} & $x$ & $\begin{array}{l}\text { within } 50 \mathrm{~cm} \mathrm{pH}>10 \text { (in } 1 \mathrm{M} \mathrm{NaF} \text { ), } \\
\text { or positive to field } \mathrm{NaF} \text { test, or andisols and } \\
\text { andic subgroups, except vitrands and vitric great } \\
\text { groups and subgroups; other indirect evidences } \\
\text { of allophane dominance in the clay size fraction, } \\
\text { or }>90 \% \mathrm{P} \text { retention (Blakemore et al., } \\
1981 \mathrm{method} \text { ) }\end{array}$ \\
\hline & $x^{-}$ & $\begin{array}{l}\mathrm{P} \text { retention between } 30 \% \text { and } 90 \% \text {; medium } \\
\mathrm{P} \text { fixers }\end{array}$ \\
\hline $\begin{array}{l}\text { Cracking clays (vertic properties): } \\
\text { very sticky plastic clay, } \\
\text { severe topsoil shrinking and swelling }\end{array}$ & $v$ & $\begin{array}{l}>35 \% \text { clay and }>50 \% \text { of } 2: 1 \text { expanding clays, } \\
\text { or coefficient of linear expansibility }>0.09 \\
\text { or vertisols and vertic groups }\end{array}$ \\
\hline $\begin{array}{l}\text { High leaching potential } \\
\text { (low buffering capacity, low ECEC) }\end{array}$ & $e$ & $\begin{array}{l}<4 \mathrm{cmol}_{\mathrm{c}} \mathrm{kg}^{-1} \text { soil as ECEC, or }<7 \mathrm{cmol}_{\mathrm{c}} \\
\mathrm{kg}^{-1} \text { soil by sum of cations at } \mathrm{pH} 7 \\
\text { or }<10 \mathrm{cmol}_{\mathrm{c}} \mathrm{kg}^{-1} \text { soil by sum of } \\
\text { cations }+\mathrm{Al}^{3+}+\mathrm{H}^{+} \text {at } \mathrm{pH} 8.2\end{array}$ \\
\hline
\end{tabular}

Modifier related to soil biological properties (new)

Low organic carbon saturation

$m$

$<80 \%$ total organic $\mathrm{C}$ saturation in the (soil organic matter depletion, topsoil (Van Noordwijk et al., 1998) compared $\mathrm{C}$ sequestration potential) with a nearby undisturbed or productive site the same soil, which is equal to $100 \%$ or $<80 \% 333 \mathrm{mM} \mathrm{KMnO}_{4}$-extractable topsoil organic carbon saturation (Blair et al., 1997) compared with a nearby undisturbed or productive site of the same soil, which is equal to $100 \%$

${ }^{a}$ All $\mathrm{pH}$ values are in 1:1 $\mathrm{H}_{2} \mathrm{O}$, unless otherwise specified. USDA Soil Taxonomy parameters and measurements are used, unless otherwise specified. Aluminum or acid saturation is defined as $\left[\left(1 \mathrm{M} \mathrm{KCl} \mathrm{Al}^{3+} /\right.\right.$ exchangeable $\mathrm{Ca}^{2+}+\mathrm{Mg}^{2+}+\mathrm{K}^{+}+\mathrm{Na}^{+}$)100]. Effective cation exchange capacity (ECEC) $=$sum of bases $+1 \mathrm{M}$ $\mathrm{KCl} \mathrm{Al}{ }^{3+}$ expressed in $\mathrm{cmol}_{\mathrm{c}} \mathrm{kg}^{-1}$ soil. $\mathrm{BS}_{7}$ and $\mathrm{BS}_{8.2}$ : percent base saturation in buffered solutions at $\mathrm{pH} 7$ and 8.2 , respectively.

dry seasons stop many pest and disease life cycles, with drought often becoming as effective in the tropics as frosts in the temperate regions. When dry seasons fail to occur, pest attacks can be stronger in the following rainy season.

Long dry seasons also favor some soil dynamics. They slow down nitrogen mineralization and leaching and cause the death of many soil microorganisms. When the rains come, there is a flush of nitrogen mineralization as the surviving bacteria involved in mineralizing organic nitrogen find themselves with an ample supply of water and energy 
Table 2

Main physical and chemical constraints relevant to agriculture in soils of the tropics

\begin{tabular}{|c|c|c|}
\hline Soil attribute (FCC units in italics) & $\begin{array}{l}\text { Million } \\
\text { hectares }\end{array}$ & $\%$ \\
\hline Soil moisture stress ( $>3$ months dry season) $-d$ & 2762 & 60 \\
\hline Low nutrient reserves $(<10 \%$ weatherable minerals $)-k$ & 1681 & 36 \\
\hline High erosion risk-LC, SC, SL, R, 30\% & 1670 & 36 \\
\hline Aluminum toxicity ( $>60 \% \mathrm{Al}$ saturation $)-a$ & 1493 & 32 \\
\hline No major chemical limitations ( $\mathrm{pH} 5.5-7.2$ ) & 1198 & 26 \\
\hline High phosphorus fixation (by $\mathrm{Fe}$ and $\mathrm{Al}$ sesquioxides) $-i$ & 1065 & 23 \\
\hline Waterlogging $-g$ & 898 & 19 \\
\hline High leaching potential- $e$ & 251 & 5 \\
\hline Calcareous (micronutrient deficiencies) $-b$ & 152 & 3 \\
\hline Cracking clays $-v$ & 150 & 3 \\
\hline Gravel- $r$ & 145 & 3 \\
\hline Shallow to rock $-R$ & 98 & 2 \\
\hline Saline $-s$ & 66 & 1 \\
\hline Sodic $-n$ & 51 & 1 \\
\hline Amorphous, volcanic $-x$ & 46 & 1 \\
\hline High organic content $(>30 \%)-O$ & 32 & 1 \\
\hline Sulfidic (cat clays) $-c$ & 7 & - \\
\hline Low organic $\mathrm{C}$ saturation $(<80 \%)-m$ & Unknown & \\
\hline Total & 4639 & \\
\hline
\end{tabular}

Adapted from Sanchez and Logan (1992), FAO (1995a) and authors' database. The sum of percentages exceeds 100 because a single soil often has more than one attribute.

from the carbon in the dead microorganisms, producing ammonium and nitrate ions that young plants can readily utilize This is known as the "Birch effect" (Birch, 1958). The moisture stress condition modifier, although strictly a soil parameter (the control section of the soil is dry [ $>1.5 \mathrm{MPa}]$ for over 90 consecutive days), is determined largely by climate and topography. The absence of the $d$ modifier indicates humid climates (udic soil moisture regimes).

\subsection{Low nutrient capital reserves $(k)$}

The phosphorus, potassium, calcium, magnesium and micronutrients that soils naturally supply to plants come from the dissolution of primary or weatherable minerals. About $36 \%$ of the tropics has soils with low (less than $10 \%$ ) reserves of weatherable minerals in their sand and silt fraction, which constitute nutrient capital reserves in the INRM context (Izac and Sanchez, 2001). This constraint is most extensive throughout the humid tropics and in the South American savannas, but is locally important in the Sahel and parts of Southern Africa. Conversely, about two-thirds of soils in the tropics have considerable reserves of the above-mentioned nutrients. The only other source of nutrient capital reserves is soil organic matter, which contains all the nitrogen and much of the phosphorus and sulfur capital of tropical soils. This is independent of weatherable minerals in the soil, although organic phosphorus and sulfur originally come from weatherable minerals. 


\subsection{High erosion risk}

The third most extensive soil constraint in the tropics is a high risk of soil erosion by water. About $36 \%$ of the soils in the tropics are at a sufficiently high risk that erosion can negatively affect plant productivity and ecosystem functions. Included in this category are soils with sharp textural breaks (SC - sandy over clayey, for example), very steep soils (more than $30 \%$ slope) and shallow soils $\left(R^{-}\right.$less than $50 \mathrm{~cm}$ deep). Although all soils, including those in flat areas are susceptible to erosion by wind and water anywhere, this table shows that about two-thirds of the tropics is not highly susceptible to soil erosion. Erosion risk does not automatically imply crop productivity losses or land degradation; something that is often assumed. The relationship between soil erosion and crop productivity is complex (Pierce et al., 1983; Follett and Stewart, 1985; Stone et al., 1985; Penning de Vries et al., 1998). Farmers in many mountainous regions have learned to farm sustainably extremely steep slopes with ingenious soil conservation practices. The key to soil erosion control is to keep the land covered with a plant canopy throughout the year. The 1951 edition of the US Soil Survey Manual states: "if continuing cultivation is assumed, generally, although not always, low fertility can be regarded as a main cause of the erosion" (Soil Survey Staff, 1951). This is perfectly applicable to the tropics.

\subsection{Aluminum toxicity (a)}

About one-third of the tropics (1.5 billion hectares) has sufficiently strong soil acidity for soluble aluminum to be toxic to most crop species. This constraint is defined as having more than $60 \% \mathrm{Al}$ saturation in some part of the top $50 \mathrm{~cm}$ of soil. A soil $\mathrm{pH}$ value of less than 5.5 usually indicates this problem (Evans and Kamprath, 1970). Aluminum toxicity is most prevalent in the humid tropics and acid savannas. This constraint is found mainly in soils classified as oxisols, ultisols and closely related inceptisols and is correlated with low nutrient capital reserves. Aluminum toxicity is usually the overwhelming constraint in these soils and must be tackled first, either by modern lime application practices, by using Al-tolerant plant species or by breeding for Al-tolerant varieties (Sanchez and Salinas, 1981). It is relevant to note that aluminum toxicity is rare in most smallholder farming areas of subhumid and semiarid Africa, except for parts of Rwanda, Burundi, Northern Zambia, Southern Congo, KwaZulu Natal Province in South Africa and in some sandy soils of Zimbabwe (Sanchez et al., 1997). Two-thirds of the tropics does not have enough aluminum saturation to worry about.

Aluminum toxicity can become a positive soil quality attribute when using Al-tolerant plants in P-deficient soils. The low $\mathrm{pH}$ facilitates the dissolution of phosphate rocks, letting, in effect, the $\mathrm{H}^{+}$ions in the soil do what a superphosphate factory does - treating rock phosphates with acids (Sanchez and Salinas, 1981). High aluminum saturation, as defined by this modifier, is also a positive attribute for rubber and tea production (Smith, 1989).

\subsection{No major chemical limitations (no symbol)}

Acid soils with surface $\mathrm{pH}$ values between 5.5 and 7.0 occupy 1.14 billion hectares and are important in all agroecological zones of the tropics. Although these soils are 
not Al-toxic, correcting soil acidity by liming might be limited to very Al-sensitive crops such as cotton and alfalfa. Users of FCC may wish to use the $a^{-}$modifier in areas where these crops are important (as shown in Table 1). Soils with no major limitations do not carry a condition modifier and are labeled by the type/substrata type (L, C, LC, for example). This attribute indicates that one-fourth of the tropics has excellent soils.

But cultivated soils with no major chemical limitations will likely develop nitrogen deficiency under continuous cropping systems without nutrient inputs. They may develop other nutrient deficiencies depending on nutrient balances. Many of the soils where smallholder farmers of subhumid Africa are facing food insecurity due to severe depletion of nitrogen and phosphorus fall into this category (Sanchez and Jama, 2002). Commonly used soil tests for nitrogen are too unreliable and rapidly changing to be used as an FCC parameter. Soil tests for phosphorus, although generally reliable, are also too labile for inclusion in FCC, in addition to their limited value in systems where mineral fertilizers are not the main kind of nutrient inputs used (Smithson and Sanchez, 2001).

The real challenge for FCC and to soil quality in general is to identify quantitative parameters that reflect these nutrient deficiencies with a sufficient level of reliability. This point is discussed later in the paper.

\subsection{High phosphorus fixation (i)}

Clayey topsoils with more than $20 \%$ iron or aluminum oxides in their clay particles "fix" or sorb large quantities of added phosphorus, transforming them into slowly soluble iron and aluminum phosphates that are not immediately available to plants. High P-fixing soils can be identified as those with clayey topsoils having red or yellowish colors indicative of high contents of iron and aluminum oxides, usually accompanied by a strong granular structure. Since high phosphorus fixation is related to high clay content, most sandy red soils do not fall in this category. This constraint is commonly considered typical of the tropics, but is only found in $23 \%$ (about 1 billion hectares) of the region. It is more extensive in the humid tropics, the South American savannas, subhumid East Africa and in clayey red soils of the dystrophic Miombo woodlands of Southern Africa.

While fixed phosphorus is unavailable to plants in the short run, it is slowly solubilized and made available to plants for a period of several years. At a time scale of 5 years, phosphorus fixation turns from a constraint into an asset, when large basal applications of phosphorus fertilizers are added to $i$ soils (Sanchez et al., 1997). Subsequent phosphorus release for several years provides sufficient phosphorus for crop production. Such phosphorus recapitalization has been successful in Brazil (Goedert, 1986) and also in East Africa (Sanchez and Jama, 2002). Banded applications of soluble P fertilizers are also an alternative practice (Yost et al., 1979, 1981; Sanchez and Jama, 2002), and the choice between these options is a matter of local costs and benefits.

Clayey subsoils that have this attribute often have sufficient anion exchange capacity to hold nitrate ions against leaching. These nitrate profile "bulges" can be accessed by trees with deep roots and then recycled to the topsoil via leaf litter (Hartemink et al., 1996). 
Another positive consequence of subsoil anion exchange capacity is the ability of the soil to hold some anions that can turn into pollutants if leached out of the soil, including phosphates.

\subsection{Waterlogging $(g)$}

Poorly drained soils cover $19 \%$ of the tropics and are distributed in all climates and geographical regions. Many of them have been converted to rice paddies, supporting intensive agriculture. An FCC interpretation specifically for wet soils grown to rice has been developed (Sanchez and Buol, 1985). Other poorly drained soils are used intensively during the dry seasons in inland valleys of Africa. Many remain as natural wetlands. This attribute is definitely positive for growing rice, the most important crop in the tropics. Soils with the $g$ modifier pose negative environmental effects due to emissions of methane and nitrous oxide, both strong greenhouse gases.

\subsection{High leaching potential (e)}

The $e$ modifier identifies very sandy soils or strongly granulated clayey soils with lowactivity clay minerals. Leaching of nutrient cations and anions represents a major loss mechanism (unless accompanied by the $i$ modifier), potentially affecting water quality if such soils are intensively fertilized. Such soils occupy only 250 million hectares, or about $5 \%$ of the tropics.

\subsection{Calcareous reaction (b)}

Soils with $\mathrm{pH}$ values above 7.2 and with free $\mathrm{CaCO}_{3}$ in the top $50 \mathrm{~cm}$, identified by effervescence with $\mathrm{HCl}$, are often deficient in micronutrients, particularly iron and zinc. Some also show imbalances between calcium, magnesium and potassium. Although they occupy a small fraction of the tropics, about 3\%, they are locally very important because of their otherwise high native fertility and are intensively utilized. Examples are the cauca valley of Colombia and parts of central plain of Luzon in the Philippines.

\subsection{Cracking clays (v)}

This is one of two instances when an FCC modifier matches with a soil order of soil taxonomy. The $v$ modifier matches the vertisol order as well as some vertic subgroups of other orders. These $v$ soils crack, shrink and swell with changes in soil moisture. They have difficult physical properties for agriculture, forestry and particularly for civil engineering. Vertisols have generally high fertility, but some are deficient in phosphorus. In spite of their dark color and clayey textures, they do not have high contents of soil organic matter. The dominance of smectitic clay minerals makes them very sticky when wet - a sure bet for vehicles getting stuck in the mud in flooded dirt roads - in comparison with the less sticky 1:1 clay minerals common in soils without the $v$ modifier. Vertisols are the dominant soils of Central India, much of eastern tropical Australia, much of the Ethiopian highlands and the Gulf Coast of Mexico. They cover 3\% of the tropics and are 
locally important in plains and valley bottoms of subhumid and semiarid tropical Africa. Savannas with $v$ soils often harbor high wild animal biomass, including the Maasai Mara, Serengeti and Luangwa national parks in Kenya, Tanzania and Zambia.

\subsection{Gravel ( $r)$}

Gravel comprises coarse fragments that range from 2 to $76 \mathrm{~mm}$ in diameter. The $r$ modifier in FCC identifies soils with layers having more than $10 \%$ gravel content by volume in the top $50 \mathrm{~cm}$ of the soil. Gravel reduces the available water capacity of soils and makes tillage difficult, often damaging equipment. Gravel is particularly widespread in West African alfisols of humid and subhumid environments. Overall, $r$ soils occupy 145 million hectares, or about $3 \%$ of the tropics.

The FCC does not address stony topsoils, except with the $r^{+++}$modifier, which denotes $>15 \%$ of rock outcroppings. Stoniness $(25-60 \mathrm{~cm}$ in diameter) exacerbates some of the negative consequences of gravelly soils just described. But in parts of Ethiopia and Eritrea, at the very limits of crop production in arid areas, stoniness is considered a positive attribute by small-scale farmers (Seppe Deckers, Catholic University of Leuven, personal communication). The soil beneath stones has more moisture because of impeded evaporation, and stony soils are locally perceived as better ones.

\subsection{Shallow depth $(R)$}

Soils shallower than $50 \mathrm{~cm}$ before encountering rock or a hard root-restricting layer pose many constraints to plant growth. They are not able to take advantage of the many positive attributes of deep rooting, such as a larger reservoir of available water and the ability to recycle nutrients leached from the topsoil. The $R$ type when combined with steep slopes results in the only truly fragile soils because if considerable erosion takes place, that is it. Most soils having this constraint are classified as rendolls, lithic subgroups of other orders of soil taxonomy, and conveniently as leptosols in the World Reference Base for Soil Resources. While extensive worldwide, shallow soils cover only a small extent of the tropical lands (98 million hectares-about 2\%).

\subsection{Salinity (s)}

Salinity is defined by the $s$ modifier, electrical conductivity greater than $0.4 \mathrm{~S} \mathrm{~m}^{-1}$ in any layer within the top meter of the soil. The FCC also includes the $s^{-}$modifier for electrical conductivities between 0.2 and $0.4 \mathrm{~S} \mathrm{~m}^{-1}$ to provide an early warning for potential salinization, as well as for use with plants highly sensitive to salinity (Smith, 1989). The osmotic tension of saline soil solutions takes water away from plants causing desiccation. In addition, salinity poses a danger of boron toxicity in some circumstances. Saline soils occupy only 66 million hectares of the tropics. This is about $20-25 \%$ of the world's saline soil area, indicating that salinity is more extensive in the temperate region.

The $s$ modifier is the only one that is rapidly growing in areal extent because of advancing secondary salinity due to poorly managed irrigation systems. This happens because of three reasons: saline waters are applied to soils with limited drainage causing 
salt accumulation; salt water from the sea intrudes into aquifers depleted of fresh water and saline water tables are rising with deforestation, particularly in Australia (Doran and Turnbull, 1997; Department of Industry, Science and Resources, 1999) because of the reduction of evapotranspiration when trees are taken out.

\subsection{Alkalinity (n)}

Alkaline or sodic soils are those with more than $15 \%$ exchangeable sodium in their effective cation exchange capacity (ECEC). The $n$ attribute identifies this constraint, while $n^{-}$denotes potential sodication. Sodic soils have extreme conditions limiting their potential for plant growth to a limited number of species, a few of them cultivated. Sodic soils occur mainly in arid environments where there is a high content of sodium in the parent material but also occur in humid or subhumid environments in coastal areas or where sodium salts (mainly carbonates of bicarbonates) seep into lakes from underground volcanic vents. This is the case of soils surrounding the soda lakes of the rift valley of Africa (Lakes Nakuru, Natron, Magadi, Elementaita and many others) that support unique types of bird fauna and shore vegetation, as distinguished from fertile soils on the shores of nearby fresh water lakes that are not affected by such sources of sodium (Lakes Turkana, Baringo and Naivasha, for example). Sodic soils are conveniently classified as solonetz in the World Reference Base for Soil Resources, but in soil taxonomy, they must have a natric horizon ( $>15 \% \mathrm{Na}$ saturation below $50 \mathrm{~cm}$ depth). This is unfortunate because the depth restriction ignores the part of the soil FCC deals with. Sodic soils cover at least 51 million hectares in the tropics out of the 135 million worldwide.

\subsection{Amorphous, volcanic soils (x)}

The $x$ modifier (for X-ray amorphous clay minerals) indicates a series of positive and negative attributes found in most andosols (FAO; World Reference Base for Soil Resources) or andisols (soil taxonomy) where the clay fraction is dominated by allophane or imogolite, products of the weathering of volcanic ejecta. The $x$ modifier separates these very distinct soils from younger volcanic soils that are composed mainly of unweathered volcanic ash, glass and cinders. Volcanic soils with the $x$ modifier cover about 25 million hectares of the tropics out a total of 37 million worldwide.

Amorphous soils have many positive attributes (Smith, 1989). They have high native fertility because of their large reserve of weatherable minerals in their sand and silt fractions that release ample amounts of phosphorus, potassium, calcium, magnesium and micronutrients to the soil solution. They also have high levels of soil organic matter that provide rapid infiltration, excellent soil structure and low bulk density. Volcanic soils provide a high nitrogen supply to plants, even though the rates of $\mathrm{N}$ mineralization are lower than in other soils with the same levels of soil organic nitrogen. This is because allophane forms complexes with organic matter, which protects it from microbial action, resulting in less organic $\mathrm{N}$ decomposition. This also decreases emissions of $\mathrm{CO}_{2}$ and $\mathrm{N}_{2} \mathrm{O}$ to the atmosphere, as well as decreases $\mathrm{N}$ immobilization.

On the negative side, amorphous soils have high phosphorus sorption capacity given the very high surface area of allophane and its affinity to fix $\mathrm{P}$ anions from the soil solution 
(Andriesse et al., 1976; Parfitt, 1989). What makes these soils different from those with the $i$ modifier (high phosphorus fixation by iron and aluminum oxides) is that the $\mathrm{P}$ sorption process itself exposes additional sites for further phosphorus fixation in the allophane, making it practically impossible to saturate the P-fixing capacity of $x$ soils. The residual effects of $\mathrm{P}$ fixation are likely to be shorter than in $i$ soils, because the $\mathrm{P}$ that is desorbed can be sorbed at another, new site. Banding $\mathrm{P}$ fertilizers and similar practices can provide sufficient quantities of fertilizer $\mathrm{P}$ for plant growth. Overall, the advantages of volcanic soils exceed their limitations.

\subsection{High organic content $(O)$}

The O type is the other FCC class that is directly related to a soil order, histosols and histic groups and subgroups of other orders: more than $12 \%$ organic $\mathrm{C}(30 \%$ organic matter) in the topsoil. Organic soils are characterized by wetness, low bulk density and low fertility (particularly nitrogen and micronutrient deficiencies). Acid ones with $\mathrm{pH}$ below 4.2 can actually trigger straight hydrogen $\left(\mathrm{H}_{3} \mathrm{O}^{+}\right)$toxicity. Some $\mathrm{O}$ soils overlying marl are not acidic. When drained, organic $\mathrm{C}$ oxidizes to $\mathrm{CO}_{2}$ causing subsidence of the soil surface and large $\mathrm{CO}_{2}$ emissions to the atmosphere. O soils are difficult to manage (Andriesse, 1988). Many actually caught fire during the El Niño droughts in Indonesia in 1977 and continued burning for years.

\subsection{Sulfidic soils (c)}

The $c$ modifier is found in soils derived from marine deposits high in sulfur compounds. Acid sulfate soils are found where sulfate ions, originally carried by seawater, are reduced to $\mathrm{H}_{2} \mathrm{~S}$ under anaerobic conditions in sediments high in organic matter (Moormann, 1963). This gives these waterlogged soils the unpleasant aroma of rotten eggs. Hydrogen sulfide reacts with iron compounds present in the soil, forming pyrite $\left(\mathrm{FeS}_{2}\right)$.

When $c$ soils are exposed to air and are low in calcium carbonate, $\mathrm{FeS}_{2}$ is oxidized to ferric sulfate and free sulfuric acid, producing $\mathrm{pH}$ values on the order of 2 or 3 . Drained acid sulfate soils are extremely infertile. The sulfate concentration and the depth at which the jarosite (a ferric sulfite) layer occurs determine whether crops can be grown at all. The free sulfuric acid dissolves clay minerals and produces large amounts of exchangeable aluminum in quantities toxic to most crops. Iron and manganese toxicities and phosphorus deficiency are common. Physical properties are very poor. Flooded rice is often grown, since under constantly reduced conditions, the $\mathrm{pH}$ is sufficiently high to eliminate aluminum toxicity. Aerobic crops are also grown with extremely careful management and keeping the water table as high as possible. Euimnoh (1984) has applied FCC to these and other problem soils of Thailand.

\subsection{Permafrost}

Although most extensive in boreal regions, the $t$ modifier outlines those soils near tropical glaciers where permafrost occurs. 


\section{The search for FCC biological condition modifiers}

Economic circumstances in many areas of the tropics, from semi-arid to humid regions, force farmers to rely largely on organic inputs, soil organic matter (SOM) or soil organic carbon (SOC) and biological processes for managing soil fertility, with mineral fertilizer inputs playing a secondary role or no role at all (Palm et al., 1997, 2001a,b). While the authors of this paper advocate the combined use of organic inputs and mineral fertilizers, FCC should explicitly address this major difference from temperate region farming, as well as the application of FCC to natural systems. Soil attributes in the tropics must, therefore, relate to the biological components and processes of soil organic matter and the organic inputs needed to maintain plant production with or without additions of mineral fertilizers. A major question, not only for tropical soils, is whether research on soil biological processes and components has advanced to the state of identifying quantitative attributes that are critical to maintain the production and environmental functions of the soil and if so, what are the threshold or critical levels in order to be included in FCC.

Soil organic matter content (except for O soils) has been deliberately omitted from FCC because there had been no clear evidence of threshold levels of SOM or SOC that define the point at which processes become dysfunctional in a soil and affect plant growth (Sanchez and Miller, 1986; Sanchez et al., 1989). That was a long time ago; since then, there has been extensive research on soil biology and soil organic matter (Woomer and Swift, 1994; Cadisch and Giller, 1997) that provide clues for the incorporation of soil biological parameters into FCC. By threshold level, we mean something analogous to the $60 \%$ Al saturation level of the $a$ modifier that flags aluminum toxicity, while its interpretation recognizes that the precise value depends on the individual plant's tolerance to this constraint (Sanchez and Salinas, 1981; Smith, 1989).

Several candidate attributes are discussed below. They are compared in Table 3 for one study in Kenya, using sites designated by farmers as "productive" or "not productive" in terms of complex smallholder production systems (Murage et al., 2000).

Table 3

Topsoil biological parameters from productive and nonproductive sites in 12 farms averaging 26 years in cultivation with significant differences of $p<0.05$ or less located in humic nitisols - alfisols $(\mathrm{FCC}=C)$ in $\mathrm{Kiambu}$ District, Kenya

\begin{tabular}{|c|c|c|c|c|}
\hline \multirow[t]{2}{*}{ Parameter } & \multicolumn{2}{|c|}{ Topsoil carbon $\left(\mathrm{mg} \mathrm{C} \mathrm{kg}^{-1}\right)$} & \multirow{2}{*}{$\begin{array}{l}\text { Saturation }(\%) \\
\text { Productive }=100\end{array}$} & \multirow[t]{2}{*}{ Probability } \\
\hline & Productive & Nonproductive & & \\
\hline Total SOC & 24,148 & 19,268 & 80 & $<0.001$ \\
\hline $\mathrm{KMnO}_{4}$-oxidizable $\mathrm{C}$ & 19,954 & 14,848 & 74 & $<0.001$ \\
\hline Particulate organic $\mathrm{C}-\mathrm{POC}(>53 \mu \mathrm{m})$ & 5753 & 3829 & 67 & $<0.01$ \\
\hline Light ludox POC (density $<1.13 \mathrm{Mg} \mathrm{m}^{-3}$ ) & 560 & 420 & 75 & $<0.05$ \\
\hline Medium ludox POC $\left(1.13-1.37 \mathrm{Mg} \mathrm{m}^{-3}\right)$ & 453 & 252 & 56 & $<0.01$ \\
\hline Heavy ludox POC (density $>1.37 \mathrm{Mg} \mathrm{m}^{-3}$ ) & 222 & 103 & 46 & $<0.05$ \\
\hline Microbial biomass $\mathrm{C}$ & 145 & 103 & 71 & $<0.01$ \\
\hline Soil respiration (mg $\mathrm{C} \mathrm{kg}^{-1}$ per day) & 61 & 47 & 71 & $<0.05$ \\
\hline
\end{tabular}

Adapted from Murage et al. (2000). We assume productive sites to be $100 \% \mathrm{C}$ saturated. 


\subsection{Soil organic carbon saturation deficit}

The concept of organic carbon saturation deficit was developed by Hassink (1997) and Van Noordwijk et al. (1998). It is simply the ratio of the present topsoil total SOC level relative to the same soil in its undisturbed or "productive" state. The threshold value is the $\% \mathrm{C}$ saturation at which the soil is reaching its limits in terms of its capacity to maintain many of its productive functions. A relative threshold value $(\% \mathrm{C}$ saturation $)$ is dimensionless and probably a more robust indicator than absolute values, expressed as concentration $\left(\mathrm{g} \mathrm{C} \mathrm{kg}^{-1}\right)$ or mass $\left(\mathrm{Mg} \mathrm{C} \mathrm{ha}{ }^{-1}\right)$. Relative values are used in FCC for the $a, i$ and $n$ modifiers for similar reasons.

The challenge is to identify the undisturbed or "productive" state (the $100 \%$ level). This is easy to do if there are nearby undisturbed natural systems with the same profile morphology, drainage and texture with depth (Sanchez et al., 1985), or if the data comes from long-term trials. Undisturbed sites are commonly found in conservation reserves or around gravesites or monuments that maintain the natural vegetation.

The reference value can also be calculated by regression equations that use factors such as \%clay + silt content and $\mathrm{pH}$ for fairly large areas such as Sumatra (Van Noordwijk et al., 1998). An alternative approach is to consider a soil considered productive by farmers as the reference value for otherwise identical soils (same profile morphology, drainage and texture with depth). Feller and Beare (1997) established limits of SOC based on the silt + clay content of tropical kaolinitic soils from several tropical countries, providing several regression equations to calculate the original SOC level and depleted levels. Lepsch et al. $(1981,1994)$ found the SOM content in the top $20 \mathrm{~cm}$ of soils that had been cropped for many years in oxisols and ultisols of Brazil without the $d$ modifier could be calculated by the equation $\% \mathrm{SOM}=0.773+0.0325$ (

Research on SOC levels in different agroecosystems in the tropics relative to levels in natural systems indicate a general pattern, with $\mathrm{C}$ saturation levels of $80 \%$ or more in crop-fallow systems with rotations greater than 10 years, as well as in agroforestry systems and $\mathrm{C}$ saturation levels lower than $80 \%$ with continuous cropping or systems with shorter rotation times (Detwiler, 1986; Palm et al., 2000). Soils of these latter systems are also often associated with lower fertility and physical problems and require higher inputs of fertilizers and tillage to raise crop yields.

Using about 25 soils with a wide range of textures from West and Central Africa, the Antilles, Brazil and India, Feller and Beare (1997) found that the topsoil SOC contents under annual crops were as low as $40 \%$ saturated relative to the equivalent uncultivated soil, but no relationship was established with plant productivity. This level was reached in 3-5 years for sandy soils and 5-10 years for clayey soils. Murage et al. (2000) found that nonproductive sites, as indicated by 12 farmers in the Kenyan highlands, were $80 \% \mathrm{C}$ saturated relative to sites of the same soils that the same farmers considered productive for a variety of crops.

\subsection{The carbon management index}

Blair et al. (1997) proposed an integrated measure of soil organic matter through the use of a fraction extracted by a dilute $(333 \mathrm{mM}) \mathrm{KMnO}_{4}$ that represents the combined 
components of labile carbon in the soil (the most common wet combustion method to determine total SOC - Walkely-Black uses concentrated potassium permanganate). Blair et al. proposed a carbon management index, as the fraction of the dilute $\mathrm{KMnO}_{4}-\mathrm{SOC}$ in a soil relative to that in an undisturbed or control soil. Murage et al. (2000) found the $\mathrm{KMnO}_{4}$ technique was sensitive to differences in land use and was also more convenient and reliable than other determinations such as light fractions and soil microbial biomass as shown in Table 3. This method produced larger labile fractions than particulate organic matter (POM) and microbial biomass methods and, therefore, probably represents several labile components in the soil. The proposed carbon management index is similar in concept to the carbon saturation deficit, but since it is a fraction of the total SOC, the absolute amounts are lower. In the work of Murage et al. (2000), the ratio was almost identical (Table 3).

\subsection{Soil organic matter fractions}

Most researchers agree that due to the multi-faceted nature and function of soil organic matter, different fractions of SOM serve different functions (Parton et al., 1989) and, therefore, critical values of these fractions could indicate soil quality (Gregorich et al., 1994; Van Noordwijk et al., 1997; Carter, 2001). It has been difficult, however, to physically isolate from soils the components that represent the different functional fractions of SOM (Magid et al., 1996). Carter (2001) proposed that critical values of the soil macroorganic matter (also referred to as light fraction and particulate organic carbon [POC]) be established as indicators of the processes related to soil physical properties.

Soil microbial biomass $\mathrm{C}, \mathrm{N}$ and $\mathrm{P}$ and light fraction SOM have been advocated for the past 20 years as fractions that best represent the more labile, nutrient-supplying aspects of soil organic matter. These parameters, at times, correlate with mineralization or crop yields, but the measured values are much too small to account for the total amounts of nutrients mineralized. Both the microbial biomass and the POC fractions can also vary considerably according to the time of sampling following addition of organic inputs and, therefore, may be too dynamic for FCC or to be a robust indicator of soil quality. The lack of a suitable measurement for estimating the labile SOC is not surprising when we consider that the fresh organic material added to soil (light fraction) is in the coarse-sized fraction of the soil; yet, the microbial biomass is located largely in the clay fraction (Palm et al., 2001a,b).

Even if different soil organic matter fractions relate to different functions, it will be difficult to pick which is the best indicator of soil quality as it may depend on the factors limiting production on a specific soil and which of the soil organic matter fractions is most closely linked to that limiting factor. Even then, as described above, the fractions have multiple functions that cannot be separated. For example, Murage et al. (2000) found that total SOC, several measures of light fraction and soil microbial $\mathrm{C}$ were all significantly higher on productive fields as compared to less productive fields on farms on alfisols in central Kenya (Table 3). Total SOC was the most sensitive soil quality indicator in this study. This is not surprising because all the soils in the study were of the same texture. From another study, in a long-term experiment on similar soils in central Kenya, Kapkiyai et al. (1999) found crop yields most highly correlated to $\mathrm{N}$ mineralization rates $\left(R^{2}=0.61\right)$ followed by various measures of POC organic matter $\left(R^{2}=0.55-0.40\right)$, then microbial biomass $\mathrm{N}\left(R^{2}=0.4\right)$ and total soil $\mathrm{N}\left(R^{2}=0.32\right)$. 
Therefore, on two very similar soils and farming systems, different SOC fractions related better to plant production. The literature is full of examples of different soil organic fractions relating to productivity. One can probably make a case for each fraction being the best indicator of soil quality in specific locations, but there is no clear consensus as to which one is best for soils in general.

\subsection{Soil biota}

The soil biotic community performs a series of processes essential to the production and environmental services of soils. These processes include decomposition, nutrient cycling, SOM formation and mineralization, soil aggregation, regulation of atmospheric trace gases and the biological control of soil-borne plant and animal pests and diseases (Lavelle et al., 1994). The quality of the soil would, therefore, depend on this biotic component (Turco and Blume, 1999; Swift, 1999; Carter, 2001). The role of soil organisms in a range of essential ecosystem functions is well established, though it is not clear what level of diversity is necessary to maintain these functions.

Current research on soil biota focuses on identifying functional groups, or guilds, of organisms that carry out specific functions in the soil (Swift, 1999). Swift and Bignell (2001) have taken the first steps at selecting key functional groups of soil organisms: (1) earthworms, which influence soil macroporosity and nutrient availability; (2) termites and ants, which also influence soil macroporosity and nutrient availability; (3) other macrofauna, which influence litter shredding; (4) nematodes, which influence turnover rates of carbon and nutrients through their role as root grazers, bacterivores, fungivores, omnivores and predators; (5) mycorrhizae, which improve water and nutrient use and reduce pathogen attacks; (6) root-nodulating bacteria, which transform atmospheric $\mathrm{N}_{2}$ into plant available forms, and (7) overall microbial biomass as an indicator of soil decomposition and nutrient cycling community. They have also established standardized field and laboratory methods for assessing these groups. The challenge will be to establish indicators and critical levels of the soil biotic functional assemblages that are needed to maintain key soil processes.

\subsection{Organic inputs}

Organic inputs play a critical role in both short-term nutrient availability and longer-term maintenance of soil organic matter in most smallholder farming systems in the tropics. They also serve as a carbon and energy source for the soil biota that carry out diverse soil processes. Thus, the quantity and quality of organic inputs could be useful as indirect indicators of the soil organic matter and nutrient-supplying capacity of the soil. Information gained over the past decade on the resource quality of organic inputs in agroecosystems has been cataloged in an organic resource database (Palm et al., 2001a,b). In addition, critical values for the nitrogen, lignin and total soluble polyphenolic contents of the organic materials and how they relate to nitrogen availability have been established (Palm et al., 1997, 2001a,b). This information on the quality of organic materials combined with information on the amounts and method and timing of application of these materials can be used in various crop and ecosystem simulation models (Parton et al., 1989; McCown et 
al., 1996). These models could then be used to establish the amounts, types and management of organic inputs necessary to maintain certain levels of soil organic matter and the soil processes associated with these levels. The model output, in other words, can provide soil quality indicators that can then be tested in the field.

\subsection{The new m modifier}

Considering the above, we propose to use the concept of organic carbon saturation deficit (Hassink, 1997; Van Noordwijk et al., 1997) as a new condition modifier denoted as $m$-for lack of more obvious letters not already used in FCC. We propose a value of $80 \%$ of the original topsoil total soil organic carbon as a trial indicator that the soil is reaching a threshold in terms of its capacity to maintain many of its functions. We also propose that the $m$ modifier be also alternatively measured by the $\mathrm{KMnO}_{4}$-extractable $\mathrm{C}$ method proposed by Blair et al. (1997), the carbon management ratio. Both measurements are included in the new version of FCC (Table 1). The other options, such as the various POC or light fractions defined in several ways, microbial biomass and soil fauna parameters, do not seem sufficiently robust at this time.

This is a ripe area for future research and we expect the $m$ modifier to be modified further as more robust data becomes available. Carbon or nitrogen mineralization rates and soil fauna may become additional FCC condition modifiers as new data warrants it. The authors call on those actively involved in linking SOM parameters with plant growth, as well as other ecosystem functions, to provide additional suggestions that would enhance the biological dimension of FCC.

In addition to being a parameter that does not change immediately with management and is related to plant growth, the carbon saturation deficit modifier also helps determine how much carbon the soil can potentially sequester. This could be useful in carbon-offset projects (Watson et al., 2000).

\section{Discussion}

\subsection{FCC at different temporal and spatial scales}

Earlier in this paper, we raised the question: at what time scales are FCC attributes refer to-days, months, years, decades or centuries? Experience in using FCC indicates that some of the condition modifiers change with management at different time scales. Our analysis is shown in Table 4.

Barring extreme disturbances like scraping off the topsoil during bulldozer land clearing, FCC type/substrata types and condition modifiers do not change in less than 1 year. The only two exceptions are the $d$ (moisture stress) and the $g$ (waterlogging) modifiers that can be overridden by irrigation and drainage, respectively (Table 4). Such rapid changes in soil moisture regime are considered in the latest version of soil taxonomy (Soil Survey Staff, 1999). Five FCC type and condition modifiers $a$ (Al toxicity), $s$ (salinity), $n$ (alkalinity), $O$ (high organic content) and $m$ (carbon saturation) can change with management in less than 10 years in the tropics, by means indicated in Table 4. Other 
Table 4

The temporal scale dimension of FCC attributes

\begin{tabular}{|c|c|c|c|c|c|}
\hline \multirow[t]{2}{*}{ FCC attribute } & \multicolumn{4}{|c|}{$\begin{array}{l}\text { Can be changed by management } \\
\text { with time (years) }\end{array}$} & \multirow[t]{2}{*}{ Means of change } \\
\hline & $<1$ & $1-10$ & $10-100$ & $>100$ & \\
\hline \multicolumn{6}{|l|}{ Type/substrata type } \\
\hline $\begin{array}{l}\mathrm{S}, \mathrm{L}, \mathrm{C}, \mathrm{SL}, \mathrm{LC} \\
\quad \mathrm{SC}, \mathrm{LC}, \mathrm{CS}, \mathrm{LS}\end{array}$ & & & & $x$ & inherent, unless severely eroded \\
\hline \multicolumn{6}{|l|}{ Condition modifiers } \\
\hline Soil moisture stress $-d$ & $\times$ & & & & temporarily by irrigation \\
\hline Low nutrient reserves $-k$ & & & & $x$ & inherent \\
\hline $\begin{array}{l}\text { High erosion risk- }-\mathrm{LC}, \mathrm{SC}, \\
\quad \mathrm{SL}, R, 30 \%\end{array}$ & & & & $x$ & $\begin{array}{l}\text { inherent; can be mitigated by } \\
\text { soil conservation practices, } \\
\text { but the risk is there }\end{array}$ \\
\hline Aluminum toxicity $-a$ & & $\times$ & & & $\begin{array}{l}\text { by Ca leaching into the subsoil, } \\
\text { more rapid in } e \text { soils } \\
\text { (Ritchey et al., 1980) }\end{array}$ \\
\hline No major chemical limitations & & & $x$ & & $\begin{array}{l}\text { by poor management, such as } \\
\text { nutrient mining (Sanchez, 2002a) }\end{array}$ \\
\hline High $\mathrm{P}$ fixation $-i$ & & & & $\times$ & $\begin{array}{l}\text { even with high } \mathrm{P} \text { fertilization, } \\
\text { positive and negative } \\
\text { attributes remain }\end{array}$ \\
\hline Waterlogging - $g$ & $\times$ & & & & by drainage \\
\hline High leaching potential- $e$ & & & & $x$ & inherent \\
\hline Calcareous $-b$ & & & $\times$ & & $\begin{array}{l}\text { by sustained leaching in slightly } \\
\text { calcareous ones }\end{array}$ \\
\hline Cracking clays $-v$ & & & & $x$ & inherent \\
\hline Gravel- $r$ & & & & $\times$ & inherent \\
\hline Shallow to rock $-R$ & & & & $\times$ & $\begin{array}{l}\text { inherent, but could be worsened } \\
\text { by erosion }\end{array}$ \\
\hline Permafrost $-t$ & & $\times^{\prime}$ & $\times$ & & $\begin{array}{l}\text { by global warming } \\
\left(x^{\prime} \text { by removal of organic litter) }\right.\end{array}$ \\
\hline Saline $-s$ & & $\times$ & & & by effective leaching \\
\hline Sodic $-n$ & & $\times$ & & & by effective leaching \\
\hline Amorphous $-x$ & & & & $\times$ & $\begin{array}{l}\text { by rapid weathering into } \\
\text { crystalline clays }\end{array}$ \\
\hline High organic content $-O$ & & $\times$ & & & $\begin{array}{l}\text { by subsidence (very fast in } \\
\text { lowland tropics) }\end{array}$ \\
\hline Sulfidic $-c$ & & & & $\times$ & inherent \\
\hline Low carbon saturation $-m$ & & $\times$ & & & $\begin{array}{l}\text { by organic input application rates } \\
\text { that exceed decomposition rate }\end{array}$ \\
\hline
\end{tabular}

We define as inherent those properties that are the product of soil genesis and cannot be easily changed by management in less than 100 years.

type/substrata type or condition modifiers can change at the decadal scale (10-100 years). These include calcareous reaction $(b)$ by sustained irrigation and subsequent leaching, permafrost $(t)$ by global warming or removal of surface organic residue and "no major chemical limitations" by nutrient depletion. In addition, erosion can result in the emergence of the $R$ (shallow to bedrock) substrata type. 
If we define "inherent" as those attributes not changing in less than a century under existing levels of management-sustainable or not - then the S, L, C, SL, LC, SC, LC, CS, LS, SR, LR and CR type/substrata types, as well as the following condition modifiers are inherent: $k$ (low nutrient capital reserves), $i$ (high $\mathrm{P}$ fixation), $e$ (high leaching potential), $v$ (cracking clays), $r$ (gravel), $x$ (amorphous clays), $c$ (sulfidic) and the various combinations that denote high erosion risk. Even though high $\mathrm{P}$ fixation by sesquioxides can be neutralized by massive applications of phosphorus fertilizers; the residual effects are not forever. Likewise, it is possible to ameliorate acid sulfate soils by careful management of the water table, but the constraint persists.

\subsection{Diffuse reflectance spectroscopy: a facilitating tool}

Assessments of soil attributes for FCC or other purposes normally rely on laboratory data with large numbers of samples required to adequately characterize spatial variability beyond the plot scale. Shepherd and Walsh (2002) developed a promising approach that estimates several soil properties simultaneously directly from diffuse reflectance spectra in rapid nondestructive ways. Using about 3000 African soils belonging to nine orders, they found that FCC attributes and other soil attributes could be calibrated directly to soil reflectance spectra with validation $r^{2}$ values ranging from 0.61 to 0.94 , using pedotransfer functions based on particle size distribution (FCC type). These attributes include: $k$ (low nutrient capital), $e$ (high leaching potential) and $a$ (Al toxicity) in FCC, soils tests for available $\mathrm{P}$ and mineralizable $\mathrm{N}$, soil carbon; available water holding capacity and soil erodibility. Soil organic carbon, ECEC and clay content can be predicted from the soil reflectance spectra with accuracy similar to duplicate laboratory determinations. In addition, soil reflectance spectra successfully predicted crop yields in an 18-year field experiment in Kenya testing different levels of fertilizer, manure and crop residue management (Shepherd and Walsh, 2000).

Because the spectral technique allows large numbers of samples to be rapidly analyzed, resources can be directed towards thorough characterization of the soil and its spatial variability within a target region. The problem of large spatial variability of many soil attributes can be overcome by making many such measurements as each one takes nanoseconds. By returning to the same site at a later time, it is possible that the amounts of soil carbon sequestered or released can be quantified in a way that may satisfy the verification requirements of the clean development mechanism of the Kyoto protocol (Watson et al., 2000). It can also help target the topsoil organic $\mathrm{C}$ content in undisturbed systems needed for identifying the $m$ modifier. Diffuse reflectance spectrometry has been used with spectral bands from satellite imagery, thus, permitting analyses at large spatial scales (Shepherd and Walsh, 2002).

\subsection{The way forward}

There are several important issues not addressed by this new version of FCC. Nutrient depletion that can take place when nutrient outputs from the soil consistently exceed nutrient inputs can turn - at a time scale of years or decades - soils having no "major chemical limitations" into ones with overwhelming limitations to plant growth and 
ecosystem functions. FCC has no way of dealing with the process of nutrient depletion at present. One possible approach is to come up with a robust index of nutrient imbalance (outputs>inputs) as an additional modifier. Such FCC modifier has to have some sort of quantitative threshold value that is widely applicable both to soils that have large nutrient capital reserves and those that do not (these have the $k$ modifier).

Likewise, FCC should address other important soil constraints, such as compaction, surface sealing and others related to air and water flow. We know that absolute values of bulk density and cone penetrometer resistance are not sufficiently robust to be relevant across a wide range of soils. Perhaps the use of dimensionless values relative to an undisturbed or a productive soil could be the way forward. The authors encourage researchers to come up with proposals for the next version.

\section{Conclusion}

The original goal to develop a soil quality paradigm akin to the current ones for air or water quality is unlikely to be fully realized because the soil is a complicated three-phase system and the solid phase consists of both inanimate compounds and live organisms. The soil quality paradigm has received substantial criticism because of the general lack of sufficient quantification and scientific rigor (Sojka and Upchurch, 1999). We fully adhere to Sojka and Upchurch's reservations because only rigorous science and robust scientific interpretations meet the test of time, while value-laden qualitative indicators may be politically and socially attractive but scientifically misleading.

The tropics are awash in such value-laden philosophies which are intuitively pleasing to many stakeholders, becoming "code phrases" that must be included in proposals to many donors if they are to have a chance of being funded. These research/development "fads" usually have a half-life of about 5 years. But new paradigms that are firmly rooted in science survive. They are usually less intuitively appealing and often face stiff initial opposition. Examples of them are soil taxonomy, aluminum toxicity as a criterion for liming and participatory research methods.

FCC is a clear alternative to qualitative approaches. Given the different views of what constitutes soil quality at present, the authors of this paper do not propose FCC as the way to go on soil quality in the tropics, but hope it constitutes a step towards this goal.

\section{References}

Andriesse, J.P., 1988. Nature and management of tropical peat soils. FAO Soils Bulletin, vol. 59. FAO, Rome. $165 \mathrm{pp}$.

Andriesse, J.P., Rosmalen, H.A.V., Muller, A., 1976. On the variability of amorphous materials in andosols and their relationships to irreversible drying and P-retention. Geoderma 16, 125-138.

Avilán, L., Perez, O., Mazzi, L., 1979. Clasificación interpretativa de suelos de los Llanos Occidentales en base a su fertilidad. Boletín Técnico, vol. 15. FONAIAP, Maracay, Venezuela.

Birch, H.F., 1958. The effect of soil drying on humus decomposition and nitrogen availability. Plant and Soil 10, 9-31. 
Blair, G.J., Lefroy, R.D.B., Singh, B.P., Till, A.R., 1997. Development and use of a carbon management index to monitor changes in soil C pool size and turnover rate. In: Cadisch, G., Giller, K.E. (Eds.), Driven by Nature: Plant Litter Quality and Decomposition. CAB International, Wallingford, UK, pp. 273-281.

Blakemore, L.C., Searle, P.L., Daly, B.K., 1981. Soil Bureau laboratory methods: A. Methods for chemical analysis of soils. New Zealand Soil Bureau Scientific Report, vol. 10A. Lower Hutt, New Zealand.

Brito, J.G., Brito, P., Mazzi, L., 1979. Sistema de clasificación interpretativa de suelos en base a su fertilidad; su aplicación a la zona sur del Lago de Maracaibo. Boletín Técnico, vol. 18. FONAIAP, Maracay, Venezuela.

Buol, S.W., 1986. Fertility capability classification system and its utilization. Soil Management Under Humid Conditions in Asia and Pacific-ASIALAND. IBSRAM, Bangkok, pp. 318-331.

Buol, S.W., Couto, W., 1981. Soil fertility capability assessment for use in the humid tropics. In: Greenland, D.J. (Ed.), Characterization of Soils in Relation to their Management for Crop Production: Examples from the Humid Tropics. Clarendon Press, London, pp. 254-261.

Buol, S.W., Sanchez, P.A., Cate, R.B., Granger, M.A., 1975. Soil fertility capability classification. In: Bornemisza, E., Alvarado, A. (Eds.), Soil Management in Tropical America. North Carolina State University, Raleigh, pp. $126-141$.

Cadisch, G., Giller, K.E. (Eds.), 1997. Driven by nature: Plant Litter Quality and Decomposition. CABI Publishing, Wallingford, UK.

Carter, M.R., 2001. Organic matter and sustainability. In: Rees, R.M., Ball, B.C., Campbell, C.D., Watson, C.A. (Eds.), Sustainable Management of Soil Organic Matter. CABI Publishing, Wallingford, UK, pp. 9-22.

CIFOR, 2000. Integrated natural resource management research in the CGIAR. Center for International Forestry Research, Bogor, Indonesia. 50 pp.

Cochrane, T.T., Sanchez, L.G., de Azevedo, L.G., Porras, J.A., Garver, C.L., 1985. Land in Tropical America, vols. 1-3. CIAT, Cali, Colombia.

Deckers, J.A., Nachtergaele, F.O., Spaargaren, O.C., 1998. World Reference Base for Soil Resources: Introduction. International Society of Soil Science, Leuven, Belgium. 165 pp.

Denton, H.P., Naderman, G.C., Buol, S.W., Nelson, L.A., 1986. Use of a technical soil classification system in evaluation of corn and soybean response to deep tillage. Soil Science Society of America Journal 50, $1309-1314$.

Detwiler, R.P., 1986. Land use change and the global carbon cycle: the role of tropical soils. Biogeochemistry 2 , $67-93$

Doran, J.W., Jones, A.J. (Eds.), 1996. Methods for Assessing Soil Quality. SSSA Special Publication, vol. 49. Soil Science Society of America, Madison, WI, USA.

Doran, J.W., Parkin, T.B., 1994. Defining and assessing soil quality. In: Doran, J.C., Coleman, D.C., Bezdicek, D.F., Stewart, B.A. (Eds.), Defining Soil Quality for a Sustainable Environment. SSSA Special Publication, vol. 35. Soil Science Society of America, Madison, WI, USA, pp. 3-21.

Doran, J.W., Parkin, T.B., 1996. Quantitive indicators of soil quality: a minimum data set. In: Doran, J.W., Jones, A.J. (Eds.), Methods for Assessing Soil Quality. SSSA Special Publication, vol. 49. Soil Science Society of America, Madison, WI, USA, pp. 25-37.

Doran, J.C., Turnbull, J.W. (Eds.), 1997. Australian Trees and Shrubs: Species for Land Rehabilitation and Farm Planting in the Tropics. ACIAR, Canberra. 384 pp.

Doran, J.C., Coleman, D.C., Bezdicek, D.F., Stewart, B.A. (Eds.), 1994. Defining Soil Quality for a Sustainable Environment. SSSA Special Publication, vol. 35. Soil Science Society of America, Madison, WI, USA.

Dumanski, J., Terry, E., Byerlee, D., Pieri, C., 1998. Performance Indicators for Sustainable Agriculture. The World Bank, Washington.

Euimnoh, A., 1984. Application of soil taxonomy to fertility capability classification of problem soils in the southeast coast of Thailand. FTTC Book Series No. 27. Problem Soils of Asia. Food and Fertilizer Technology Center, Taipei, pp. 169-180.

Evans, C.E., Kamprath, E.J., 1970. Lime response as related to percent aluminum saturation, soil solution aluminum and organic matter content. Proceedings - Soil Science Society of America 34, 893-896.

FAO, 1981. Report on the agro-ecological zones project, vol. 3. Methodology and results for South and Central America. World Soil Resources Report 48/3. FAO, Rome. 251 pp.

FAO, 1995a. Digital Soil Map of the World and Derived Soil Properties. FAO, Rome. 
FAO, 1995b. Global and national soil and terrain digital databases (SOTER). FAO World Soils Resources Report 74, Rev. 1. Rome.

Feller, C., Beare, M.H., 1997. Physical control of soil organic matter dynamics in the tropics. Geoderma 79, 69-116.

Follett, R.F., Stewart, B.A. (Eds.), 1985. Soil Erosion and Crop Productivity. American Society of Agronomy, Madison, WI, USA. 533 pp.

Franzel, S., Scherr, S. (Eds.), 2002. Trees on Farm: Assessing the Adoption Potential of Agroforestry Practices in Africa. CABI Publishing, Wallingford, UK.

Franzel, S., Cooper, P.J.M., Denning, G.L., 2001. Scaling-up the benefits of agroforestry research: lessons learned and research challenges. Development in Practice 11, 524-534.

Goedert, W.J., 1986. Solos dos Cerrados: Tecnologías e estratégias de manejo. Livraria Nobel, São Paulo. 422 pp.

Gregorich, E.G., Carter, M.R., Angers, D.A., Monreal, C.M., Ellert, B.H., 1994. Towards a minimum data set to assess soil organic matter quality in agricultural soils. Canadian Journal of Soil Science 74, 367-385.

Hartemink, A.E., Buresh, R.J., Jama, B., Janssen, B.H., 1996. Soil nitrate and water dynamics in Sesbania fallows, weed fallows, and maize. Soil Science Society of America Journal 60, 568-574.

Hassink, J., 1997. The capacity of soils to preserve organic C and N by their association with clay and silt particles. Plant and Soil 191, 77-87.

Izac, A.-M.N., Sanchez, P.A., 2001. Towards a natural resource management paradigm for international agriculture: the example of agroforestry research. Agricultural Systems 69, 5-25.

Kapkiyai, J.J., Karanja, N.K., Quresh, J.N., Smithson, P.C., Woomer, P.L., 1999. Soil organic matter and nutrient dynamics in a Kenyan nitisol under long-term fertilizer and organic input management. Soil Biology \& Biochemistry 31, 1773-1782.

Karlen, D.L., Mausbach, M.J., Doran, J.W., Cline, R.G., Harris, R.F., Schuman, G.E., 1997. Soil quality: a concept, definition, and framework for evaluation (a guest editorial). Soil Science Society of America Journal $61,4-10$.

Lal, R., Sanchez, P.A. (Eds.), 1992. Myths and Science of Soils of the Tropics. SSSA Special Publication, vol. 29. Soil Science Society of America, Madison, WI, USA.

Lavelle, P., Dangerfield, M., Fragoso, C., Eschenbrenner, V., Lopez-Hernandez, D., Pashanasi, B., Brussard, L., 1994. The relationship between soil macrofauna and tropical soil fertility. In: Woomer, P.L., Swift, M.J. (Eds.), The Biological Management of Soil Fertility. Wiley, Chichester, UK, pp. 137-170.

Liegel, L.H., 1986. 1986 progress report for growth and site relationships of Caribbean pine in Jamaica, Costa Rica, Trinidad and Venezuela. Project AID/SCI/E2/06. USDA Forest Service, Washington.

Lepsch, I.F., Silva, N.M., Espironelo, A., 1981. Relacão entre a materia organica e textura de solos sob cultivo de algodão e cana-de-açucar no Estado de São Paulo. Bragantia 41, 231 - 236.

Lepsch, I.F., Menk, J.R.F., Oliveira, J.B., 1994. Carbon storage and other properties of soils under agriculture and natural vegetation in São Paulo State, Brazil. Soil Use and Management 10, 34-42.

Lin, C.F., 1984. Fertility capability classification as a guide to N-fertilization for lowland rice. FTTC Book Series No. 27. Problem Soils of Asia. Food and Fertilizer Technology Center, Taipei.

Lin, C.F., 1985. Fertility capability classification (FCC) as a guide to PK-fertilization of lowland rice. Soil Taxonomy. Review and Use in the Asia-Pacific Region. Food and Fertilizer Technology Center, Taipei, pp. $103-120$

Magid, J., Gorissen, A., Giller, K.E., 1996. In search of the elusive 'active' fraction of soil organic matter: three size-density fractionation methods for tracing the fate of homogeneously ${ }^{14} \mathrm{C}$-labelled plant materials. Soil Biology \& Biochemistry 28, 89-99.

McCown, R.L., Hammer, G.L., Hargreaves, J.N.G., Holzworth, D.P., Freebairn, D.M., 1996. APSIM: a novel software system for model development, model testing and simulation in agricultural systems research. Agricultural Systems 50, 255-271.

Moormann, F.R., 1963. Acid sulfate soils (cat clays) of the tropics. Soil Science 95, 271-275.

Murage, E.W., Karanja, N.K., Smithson, P.C., Woomer, P.L., 2000. Diagnostic indicators of soil quality in productive and non-productive smallholders' fields of Kenya's Central Highlands. Agriculture, Ecosystems and Environment 79, 1-8.

Oliveira, J.B., 1978. Classificacão de solos da quadrícula de Campinas. Boletím Técnico, vol. 59. Instituto Agronomico de Campinas, Piracicaba, SP, Brazil. 
Palm, C.A., Myers, R.J.K., Nandwa, S.M., 1997. Combined use of organic and inorganic nutrient sources for soil fertility maintenance and replenishment. In: Buresh, R.J., Sanchez, P.A., Calhoun, F.E. (Eds.), Replenishing Soil Fertility in Africa. SSSA Special Publication, vol. 51. Soil Science Society of America, Madison, WI, USA, pp. 193-218.

Palm, C.A., et al., 2000. Carbon sequestration and trace gas emissions in slash-and-burn and alternative land uses in the humid tropics. Alternatives to Slash and Burn Program Climate Change Working Group Final Report Phase II. International Centre for Research in Agroforestry, Nairobi. 32 pp.

Palm, C.A., Gachengo, C.N., Delve, R.J., Cadisch, G., Giller, K.E., 2001a. Organic inputs for soil fertility management in tropical agroecosystems: application of an organic resource database. Agriculture, Ecosystems and Environment 83, 27-42.

Palm, C.A., Giller, K.E., Mafongoya, P.I., Swift, M.J., 2001b. Management of organic matter in the tropics: translating theory into practice. Nutrient Cycling in Agroecosystems 63, 63-75.

Paredes, G.P., 1986. Le systeme de classification des sols par capacite de fertilite de L'Universite de L'Etat de Carolina du Nord (USA) permet d'apprecier les principales constraintes de fertilite des sols de L'Amazonie Peruvienne. These annexe a la dissertation originale presentee. Univestite Gembloux, Belgique.

Parfitt, R.L., 1989. Phosphate reactions with natural allophane, ferrihydrite and goethite. Journal of Soil Science 40, 359-369.

Parton, W.J., Swift, R.L., Sanchez, P.A., Stewart, J.W.B., 1989. Modeling soil organic matter dynamics in tropical soils. In: Coleman, D., Bohlool, B., Uehara, G. (Eds.), Dynamics of Soil Organic Matter in Tropical Ecosystems. University of Hawaii Press, Honolulu, pp. 153-171.

Penning de Vries, F.W.T., Agus, F., Kerr, J. (Eds.), 1998. Soil Erosion at Multiple Scales, Principles and Methods for Assessing Causes and Impacts. CABI Publishing, Wallingford, UK.

Pierce, F.J., Larson, W.E., Dowdy, R.H., Graham, W.A.P., 1983. Productivity of soil: assessing long-term changes due to erosion. Journal of Soil and Water Conservation 38, 39-44.

Pinstrup-Andersen, P., Pandhya-Lorch, R., Rosegrant, M.W., 1999. World Food Prospects: Critical Issues for the Early Twenty-First Century. International Food Policy Research Institute, Washington.

Ritchey, K.D., Souza, D.M.G., Lobato, E., Correa, O., 1980. Calcium leaching to increase rooting depth in Brazilian savannah oxisols. Agronomy Journal 72, 40-44.

Sanchez, P.A., 1997. Changing tropical soil fertility paradigms: from Brazil to Africa and back. In: Moniz, A.C., et al., (Eds.), Plant-Soil Interactions at Low pH. Brazilian Society of Soil Science, Piracicaba, SP, pp. 19-28.

Sanchez, P.A., 2002a. Soil fertility and hunger in Africa. Science 295, 2019-2020.

Sanchez, P.A., 2002b. Soil science as a major player in world development. 17th World Congress of Soil Science, Keynote Lectures. The Soil and Fertilizer Society of Thailand, Bangkok, pp. 53-64.

Sanchez, P.A., Buol, S.W., 1985. Agronomic taxonomy for wetland soils. Wetland Soils: Characterization, Classification and Utilization. International Rice Research Institute, Manila, pp. 207-227.

Sanchez, P.A., Jama, B.A., 2002. Soil fertility replenishment takes off in East and Southern Africa. In: Vanlauwe, B., Sanginga, N., Merckx, R. (Eds.), Integrated Nutrient Management in Sub-Saharan Africa. CAB International, Wallingford, UK, pp. 23-45.

Sanchez, P.A., Logan, T.J., 1992. Myths and science about the chemistry and fertility of soils in the tropics. In: Lal, R., Sanchez, P.A. (Eds.), Myths and Science of Soils of the Tropics. SSSA Special Publication, vol. 29. Soil Science Society of America, Madison, WI, USA, pp. 35-46.

Sanchez, P.A., Miller, R.H., 1986. Organic matter and soil fertility management in acid soils of the tropics. Transactions 13th Congress of the International Society of Soil Science, Hamburg, Germany, pp. 609-625.

Sanchez, P.A., Salinas, J.G., 1981. Low-input technology for managing oxisols and ultisols in tropical America. Advances in Agronomy 34, 279-406.

Sanchez, P.A., Couto, W., Buol, S.W., 1982. The fertility capability soil classification system: interpretation, applicability and modification. Geoderma 27, 283-309.

Sanchez, P.A., Palm, C.A., Davey, C.B., Szott, L.T., Russell, C.E., 1985. Tree crops as soil improvers in the humid tropics. In: Cannell, M.G.R., Jackson, J.E. (Eds.), Trees as Crop Plants. Institute of Terrestrial Ecology, Edinburgh, UK, pp. 327-358.

Sanchez, P., Palm, C.A., Szott, L.T., Cuevas, E., Lal, R., 1989. Organic input management in tropical agroecosystems. In: Coleman, D., Bohlool, B., Uehara, G. (Eds.), Dynamics of Soil Organic Matter in Tropical Ecosystems. University of Hawaii Press, Honolulu, pp. 125-152. 
Sanchez, P.A., et al., 1997. Soil fertility replenishment in Africa: an investment in natural resource capital. In: Buresh, R.J., Sanchez, P.A., Calhoun, F. (Eds.), Replenishing Soil Fertility in Africa. SSSA Special Publication, vol. 51. Soil Science Society of America, Madison, WI, pp. 1-46.

Shepherd, K.D., Walsh, M.G., 2000. Diffuse Reflectance Spectrometry in the NARL Long-Term ExperimentPreliminary Results. International Centre for Research in Agroforestry, Nairobi.

Shepherd, K.D., Walsh, M.G., 2002. Development of reflectance spectral libraries for characterization of soil properties. Soil Science Society of America Journal 66, 988-998.

Smaling, E.M.A., 1993. An agro-Ecological Framework for Integrated Nutrient Management with Special Reference to Kenya. Wageningen Agricultural University, Wageningen, Netherlands. 250 pp.

Smith, C.W., 1989. The fertility capacity classification system (FCC)-3rd approximation: a technical soil classification system relating pedon characterization data to inherent fertility characteristics. $\mathrm{PhD}$ dissertation, North Carolina State University, Raleigh. 430 pp.

Smith, C.W., Sanchez, P.A., Buol, S.W., 1990. Implications of soil mineralogy in the soil fertility capability classification (FCC) system. Transactions 14th International Congress of Soil Science (Kyoto). Japanese Society of Soil Science, Kyoto, pp. 4-9.

Smithson, P.C., Sanchez, P.A., 2001. Plant nutritional problems in marginal soils of developing countries. In: Ae, N., Arihira, J., Okada, K., Srinivasan, A. (Eds.), Plant Nutrient Acquisition: New Perspectives. SpringerVerlag, Tokyo, pp. 32-68.

Soil Survey Staff, 1951. Soil survey manual. USDA Agricultural Handbook, vol. 18. US Government Printing Office, Washington, p. 261.

Soil Survey Staff, 1999. Soil taxonomy, a basic system of soil classification for making and interpreting soil surveys. USDA Agricultural Handbook, 2nd ed. Natural Resources Conservation Service, vol. 436. US Department of Agriculture, Washington. 869 pp.

Sojka, R.E., Upchurch, D.R., 1999. Reservations regarding the soil quality concept. Soil Science Society of America Journal 63, 1039-1054.

Sornsumran, S., 1985. Soil fertility capability classification for paddy rice and cassava in Chachoengsao and Nakhon Nayok provinces. MS thesis, Gadjah Mada University, Yogyakarta, Indonesia.

Stone, J.R., Gilliam, J.W., Cassel, D.K., Daniels, R.B., Nelson, L.A., Kleiss, H.G., 1985. Effects of erosion and landscape position on the productivity of piedmont soils. Soil Science Society of America Journal 49, 987-991.

Swift, M.J., 1999. Integrating soils, systems and society. Nature and Resources 35 (4), 12-20.

Swift, M.J., Bignell, D., 2001. Standard methods for the assessment of soil biodiversity and land-use practice. ASB-Lecture Note 6B. International Centre for Research in Agroforestry, South East Asian Regional Research Programme, Bogor, Indonesia.

Van Noordwijk, M., Cerri, C., Woomer, P.L., Nugroho, K., Bernoux, M., 1997. Soil organic carbon dynamics in the humid tropical forest zone. Geoderma 79, 187-225.

Van Noordwijk, M., Hairiah, K., Woomer, P.L., Murdiyarso, D., 1998. Criteria and indicators of forest soils used for slash-and-burn agriculture and alternative land uses in Indonesia. The Contributions of Soil Science to the Development and Implementation of Criteria and Indicators of Sustainable Forest Management. SSSA Special Publication, vol. 53. Soil Science Society of America, Madison, WI, USA, pp. $137-153$

Watson, R.T., Noble, I.R., Bolin, B., Ravindranath, N.H., Verardo, D.J., Dokken, D.J. (Eds.), 2000. Land Use, Land-Use Change and Forestry. Cambridge Univ. Press, UK.

White, P.F., Oberthur, T., Sovuthy, P., 1997. The soils used for rice production in Cambodia. A Manual for Their Identification and Management. International Rice Research Institute, Manila. 70 pp.

Wood, S., Sebastian, K., Scherr, S.J., 2000. Pilot analysis of global ecosystems: agroecosystems. International Food Policy Research Institute and World Resources Institute, Washington. 110 pp.

Woomer, P.L., Swift, M.J. (Eds.), 1994. The Biological Management of Tropical Soil Fertility. Wiley, Chichester, UK.

WRI, 1990. World Resources 1990-91: A Guide to the Global Environment. Oxford Univ. Press, New York, pp. $286-290$.

WRI, 1992. World Resources 1992-93. Toward sustainable development. Oxford Univ. Press, New York, pp. $281-284$. 
Yost, R.S., Kamprath, E.J., Lobato, E., Naderman, G., 1979. Phosphorus response of corn on an oxisol as influenced by rates and placement. Soil Science Society of America Journal 43, 338-343.

Yost, R.S., Kamprath, E.J., Naderman, G., Lobato, E., 1981. Residual effects of phosphorus application on a high phosphorus adsorbing oxisol of central Brazil. Soil Science Society of America Journal 45, 540-543.

Yost, R.S., Li, Z.C., Smith, C.W., Benites, J., Nachtergaele, F., 1997. Merging Databases and Decision-Aids: Linking an Updated Soil Fertility Capability Classification (FCC) with the WISE (World Inventory of Soil Emission Potential) Database FAO, Rome. 